\title{
Analysis of Leucine-rich repeat kinase 2 (LRRK2) and Parkinson protein 2 (parkin, PARK2) genes mutations in Slovak Parkinson disease patients
}

\author{
Csaba Bognar ${ }^{1}$, Marian Baldovic ${ }^{1}$, Jan Benetin ${ }^{2}$, Ludovit Kadasi ${ }^{1,3}$ and Andrea Zatkova ${ }^{3}$ \\ ${ }^{1}$ Department of Molecular Biology, Faculty of Natural Sciences, Comenius University, Bratislava, Slovak Republic \\ ${ }^{2}$ Clinics of Neurology, Universty Hospital, Bratislava, Slovak Republic \\ ${ }^{3}$ Institute of Molecular Physiology and Genetics, Slovak Academy of Sciences, Bratislava, Slovak Republic
}

\begin{abstract}
Parkinson disease (PD) is a chronic neurodegenerative movement disorder characterized by selective loss of nigrostriatal dopaminergic neurons and formation of Lewy bodies. Clinical manifestations include motor impairments involving tremor, bradykinesia, postural instability and rigidity.

Using dHPLC method we screened exons $31,35,41,48$ of the Leucine-rich repeat kinase 2 (LRRK2) gene and exons 2, 6 and 7 of Parkinson protein 2 (parkin, PARK2) genes in a cohort of 216 consecutive, unrelated Slovak patients with familial or sporadic PD, including early and late onset. By this means we aimed to detect the most common pathogenic mutations within LRRK2 (Arg1441Cys, Arg1441Gly, Arg1628Pro, Tyr1699Cys, Gly2019Ser, Ile2020Thr, Gly2385Arg) and parkin genes responsible for late and early onset forms of disease, respectively. However, none of these mutations was identified in our cohort. Heterozygous point mutation p.Arg275Trp in exon 7 of parkin gene was identified in one patient with age at onset 61 years. Furthermore, we observed the presence of one exonic ( $L R R K 2$ ex 48: 7155A $>\mathrm{G}$ ) and eight intronic polymorphisms (in $L R R K 2:$ IVS35+23T $>\mathrm{A}$, IVS47-91insGCCAT, IVS47-91insGCAT, IVS47-41 A $>$ G, IVS47-9delT, IVS47-20C > T, IVS47-90A >G, in parkin: IVS2+25T>C), three of which were novel.
\end{abstract}

Key words: dHPLC - p.Arg275Trp - Parkinson disease - Parkin polymorphism - LRRK2 polymorphisms

\section{Introduction}

The Parkinson's disease (PD) is the second most common progressive neurodegenerative brain disorder caused by loss of nigrostriatal dopaminergic neurons, which affect the control of body movements, with formation of inclusions (Lewy bodies) in surviving neurons. It affects $1-2 \%$ of the global population above 65 years and its prevalence increases to approximately $4 \%$ in those above 85 years (Calne et al. 1992; Polymeropoulos et al. 1996; Nussbaum et al. 1997; Biswas et al. 2006). The disease is characterized by bradykinesia, resting tremor, rigidity and postural instability (Nussbaum et al. 1997) and it is generally con-

Correspondence to: Csaba Bognár, Department of Molecular Biology, Faculty of Natural Sciences, Comenius University, Mlynská dolina B2-211, 84215 Bratislava, Slovak Republic

E-mail: bogeecs@gmail.com sidered to be the result of the interaction between genetic and environmental factors (Calne et al. 1987; Eriksen et al. 2005).

Mutations responsible for the recessive early-onset PD (EOPD) were identified in parkin (PRKN, PARK2; MIM 602544) (Kitada et al. 1998), DJ-1 (PARK7; MIM 602533) (Bonifati et al. 2003) and PTEN-induced kinase 1 (PINK1, PARK6; MIM 608309) (Valente et al. 2004), while mutations within Leucine-rich repeat kinase 2 (LRRK2, PARK8; MIM 609007) (Paisan-Ruiz et al. 2004; Zimprich et al. 2004a) and $\alpha$-synuclein (SNCA, PARK1, PARK4; MIM163890) (Polymeropoulos et al. 1997) are associated with autosomal dominant, late onset form of PD.

Leucine-rich repeat kinase 2 (LRRK2, PARK8) gene

The PARK8 locus containing approximately 116 genes was mapped to chromosome position $12 \mathrm{q}$ in a large Japanese 
family presenting with autosomal dominant parkinsonism (Funayama et al. 2002) and later on this finding was confirmed also in other countries. The PARK8-linked families are characterized by late onset of the disease, i.e. over 50 years (Funayama et al. 2002; Paisan-Ruiz et al. 2004; Zimprich et al. 2004b; Bialecka et al. 2005; Di Fonzo et al. 2006a).

The LRRK2 gene covers $145 \mathrm{~kb}$ of genomic DNA and is split into 51 exons that encode for a large 2527 amino acid protein dardarin (derived from "dardara", the Basque word for tremor) that belongs to a group of the Ras/GTPase superfamily, termed ROCO. This protein is highly conserved among vertebrates and is multifunctional with five functional domains: LRR (Leucine-rich repeat), Ras GTPase (Roc), COR (C-terminal of Roc), MAPKKK (tyrosine kinase-like mitogen-activated protein kinase kinase kinase) and a WD-40 (Zimprich et al. 2004a). Dardarin is functionally implicated in substrate binding, phosphorylation and protein-protein interactions (Moore et al. 2005; Punia et al. 2006).

LRRK2 is postulated to be a key molecule in the etiology of both familial and sporadic PD. However, the molecular mechanism whereby mutant LRRK2 causes loss of dopaminergic neurons has not yet been confirmed. This is due to the lack of consensus about the true physiological substrate or true function of LRRK2. Ohta et al. (2011) demonstrated for the first time that LRRK2 directly phosphorylates serine/ threonine kinase Akt1 (also known as protein kinase B1) that is the central molecule that transduces signals from receptors for growth factors and hormones to insure cell survival and protection of cells from apoptosis. Ser473, one of two amino acids essential for Akt1 activation, was the target site for LRRK2 (Dudek et al. 1997; Manning and Cantley 2007).

The large number of missense mutations has been found within LRRK2 with varying degrees of proof of pathogenicity. The disease-associated mutations R1441C, G2019S and I2020T exhibited reduced interaction with and phosphorylation of Akt1, suggesting one possible mechanism for the neurodegeneration caused by LRRK2 mutations (Ohta et al. 2011).

Some mutations are surprisingly common: R1441G is found in a large proportion of Basque cases (Simón-Sánchez et al. 2006), G2019S in Europeans, especially among those with Semitic ancestry (Kachergus et al. 2005; Ozelius et al. 2006) and both G2385R (Mata et al. 2005; Di Fonzo et al. 2006a; Tan et al. 2007; Choi et al. 2008) and R1628P (Ross et al. 2008) explain a large proportion of disease among eastern Asian peoples. The penetrance of all the mutations is not clear, but the G2019S mutation is nearly fully penetrant by the age of 80 (Kachergus et al. 2005; Healy et al. 2008).

\section{Parkinson protein 2 (PARK2, parkin) gene}

An autosomal recessive form of familial juvenile parkinsonism (AR-JP, PARK2; OMIM 602544), defined as onset before age 40, was described in a Japanese family by Takahashi et al. (1994). The gene was initially mapped to the long arm of chromosome 6 (6q25.2-q27), a region deleted in some of the AR-JP patients.

In juvenile-onset $\mathrm{PD}$ classic symptoms of $\mathrm{PD}$, such as bradykinesia, rigidity, and tremor are present, but it also has its specificities in several aspects. Matsumine et al. (1998) noted that early-onset parkinsonism with diurnal fluctuation (EPDF) is also a dopa-responsive form of parkinsonism and is associated with selective degeneration in the zona compacta of the substantia nigra without Lewy body formation. A distinguishing feature of this phenotype is a benefit from sleep with lessening of parkinsonian symptoms after awakening (Matsumine et al. 1998).

Kitada and co-workers found out that the PARK2 (parkin, also known as E3 ubiquitin protein ligase) gene spans more than $500 \mathrm{~kb}$ and has 12 exons. Sasaki et al. suggested that a functional parkin protein may be required for Lewy body formation (Takahashi et al. 1994; Kitada et al. 1998; Matsumine et al. 1998; Sasaki et al. 2004). This protein contains five functional domains, namely the N-terminal ubiquitin-like (UBL) domain, the unique parkin (UP) domain, and the C-terminal RING1, in-between RING (IBR) and RING2 domains. It has been shown that parkin is an E3 ubiquitin ligase that is able to catalyze the addition of ubiquitin molecules to specific substrates, which targets these substrates for degradation via the ubiquitin proteasome system (Shimura et al. 2000; Haylett et al. 2011).

Mutations in the PARK2 gene are those most frequently identified among patients with early-onset of Parkinson's disease (EOPD) (age at onset $\leq 50$ years). They account for up to $50 \%$ of autosomal recessive early-onset parkinsonism (AREP) and 15-20\% of sporadic EOPD (Kitada et al. 1998). Over 100 types of mutations including sequence substitutions, insertions, and exonic deletions/duplications (or dosage mutations) in the PARK2 gene have been described in diverse ethnic groups (Hedrich et al. 2004), majority of which are loss-of- function mutations affecting one or more of the functional domains.

Although PD causative mutations of parkin are usually homozygous or compound heterozygous, previous studies have hypothesized that the heterozygous mutations may cause haploinsufficiency of the gene and increase the risk for PD (Foroud et al. 2003; Sun et al. 2006; Wang et al. 2010). Parkin is particularly susceptible to whole exon deletions and duplications; it is therefore imperative to consider exon dosage mutations when performing mutation screening of parkin (Lücking et al. 2000; Periquet et al. 2003). The results of Wang et al. (2010), showed clearly that most (>60\%) of the dosage parkin mutations identified in both the familial and sporadic EOPD cases were heterozygotes, and that heterozygous dosage mutations alone can increase the overall risk for development of EOPD, especially of AREP 
(autosomal-recessive early-onset parkinsonism) subjects $(p=0.004)$. Moreover, the carrier status of dosage mutations has significant impact on the clinical features such as age at onset, characteristics of initial signs, and later complications in both AREP and sporadic EOPD patients. The haploinsufficiency may be caused more by dosage mutations than by point mutations. However, the dosage heterozygotes may not directly lead to PD because there were members in AREP families for dosage heterozygotes who were not affected. Other mutations such as a second point mutation may be needed to constitute a complete genetic contribution to the disease (Wang et al. 2010).

In our study we have analyzed selected exons of LRKK2 and PARK2 genes, since in these genes/exons the most frequent pathogenic mutations causing PD have been described.

\section{Materials and Methods}

216 PD patients (119 men, 97 women) were included in the study. Written informed consent was obtained from all individuals before participation in the study. All patients were of the same ethnic middle European ancestry. The clinical diagnosis of Parkinson's disease was confirmed by neurologists. Twenty-eight patients (12.9\%) reported a positive family history of parkinsonism. The Hoehn-Yahr stage was between $1-5$ (mean 2.6). The average age in this cohort was 68 years (35-91), while the mean age at onset (Table 1) was 59.77 years (range $30-86$ ). Thirty-nine patients were defined as the early onset parkinsonism ( $\leq 50$ years).

All subjects were screened for possible mutations within selected exons in LRRK2 (exons 31, 35, 41 and 48) and parkin (2, 6 and 7) genes using dHPLC (denaturing high-performance liquid chromatography). By this means we also aimed to test for presence of the most common mutations and polymorphism reported in these exons that are responsible for both the early and the late onset form of the disease.

Genomic DNA was isolated from peripheral blood using Gentra Puregene Blood Kit according to the manufacturers'
Table 1. Distribution of age at onset of the 216 PD subjects

\begin{tabular}{ccc}
\hline Age at onset (years) & Number of subjects & Percentage \\
\hline $0-29$ & 0 & 0 \\
$30-39$ & 11 & 5.09 \\
$40-49$ & 28 & 12.97 \\
$50-59$ & 56 & 25.92 \\
$60-69$ & 76 & 35.19 \\
$70-79$ & 44 & 20.37 \\
$80-89$ & 1 & 0.46 \\
Total & 216 & 100 \\
\hline
\end{tabular}

protocol (QIAGEN Sciences, USA). Primers were designed using Primer3 software (http://frodo.wi.mit.edu/primer3/) containing flanking intronic sequences (Table 2).

PCR products were generated with $100 \mathrm{ng}$ DNA template in $3 \mu \mathrm{l} 10 \times$ PCR buffer (GeneCraft, Ares Bioscience, Cologne, Germany), $0.15 \mu \mathrm{l}$ of $10 \mathrm{mmol} / \mathrm{l}$ each dNTP (Promega), $0.9 \mu \mathrm{l}$ of $50 \mathrm{mmol} / \mathrm{l} \mathrm{MgCl} 2,1 \mu \mathrm{l}$ of $5 \mu \mathrm{mol} / \mathrm{l}$ each primer (Sigma-Genosys, USA) and 1unit BioTherm Taq DNA polymerase (GeneCraft, Ares Bioscience, Cologne, Germany) in a total volume of $30 \mu \mathrm{l}$. PCR conditions were: $94^{\circ} \mathrm{C}$ for $4 \mathrm{~min}$ followed by 30 cycles of $94^{\circ} \mathrm{C}$ for $25 \mathrm{~s}$, the annealing temperatures were $57^{\circ} \mathrm{C}$ (LRRK2ex31), $59^{\circ} \mathrm{C}$ (LRRK2ex35, ex48, PARKINex2, ex6, ex7), $60^{\circ} \mathrm{C}$ (LRRK2ex41) for $25 \mathrm{~s}$, and $72^{\circ} \mathrm{C}$ for $40 \mathrm{~s}$, with a final extension step of $72^{\circ} \mathrm{C}$ for $5 \mathrm{~min}$. PCR products of each exonic PCR amplification products were electrophoresed on a $1.5 \%$ agarose gel at $150 \mathrm{~V}$ for $60 \mathrm{~min}$ and visualized by UV illumination staining with SybrGreen I (Invitrogen, Grand Island, NY, USA). SybrGreen I was included in the loading dye and after mixing with the sample final concentration was $6 \times$.

DHPLC analysis was carried out on an automated dHPLC device equipped with a DNA separation column (WAVE Transgenomic, Omaha, NE, USA) according to the manufacturer's protocol. $25 \mu \mathrm{l}$ of each PCR product (containing 10-100 ng DNA) was denatured at $94^{\circ} \mathrm{C}$ for $5 \mathrm{~min}$ and then gradually reannealed by decreasing the sample temperature from $94^{\circ} \mathrm{C}$ to $54^{\circ} \mathrm{C}$ over a period of $30 \mathrm{~min}$. To perform

Table 2. Primer sequences, temperature of annealing, product size (bp) and temperature of DHPLC analyses

\begin{tabular}{lllccc}
\hline Exon & Forward (5'-3”) & Reverse $\left(5^{\prime}{ }^{\prime}-3^{\prime}\right)$ & $\begin{array}{c}\text { Annealing } \\
\left({ }^{\circ} \mathrm{C}\right)\end{array}$ & $\begin{array}{c}\text { Product } \\
\text { size }(\mathrm{bp})\end{array}$ & $\begin{array}{c}\mathrm{T}_{\text {DHPLC }} \\
\left({ }^{\circ} \mathrm{C}\right) \text { F/R }\end{array}$ \\
\hline Lrrk2 ex31 & ATGTGAGCAGGCCCAGTTT & AACAAGGAAAGAAAACCCACAA & 57 & 392 & $56.6 / 59.2$ \\
Lrrk2 ex35 & CATTTGCTCAACAAGGTTGG & GCTGCCTTCCAAACAAGTAAA & 59 & 353 & $55.7 / 57.3$ \\
Lrrk2 ex41 & GATGCTTGACATAGTGGACATTT & TGTTTCCTTTTGACTCTTCTGA & 60 & 351 & $58.0 / 59.1$ \\
Lrrk2 ex48 & GCAATAGTCTAGCTTGTTTAGTTTTCA & TCAGAGGCAGAAAGGAAGAAA & 59 & 377 & $54.9 / 56.9$ \\
Parkin ex2 & TAAGGGCTTCGAGTGATGCT & GCATGAGCAATGGAGCTG & 59 & 272 & $60.3 / 62.7$ \\
Parkin ex6 & ACTGTGGAAACATTTAGAGGAAAAA & GCTCGTGTGGCAGAACAATA & 59 & 297 & $56.2 / 59.5$ \\
Parkin ex7 & GCTGCCTTTCCACACTGAC & TTGTTCTTCTGTTCTTCATTAGCA & 59 & 248 & 60.6 \\
\hline
\end{tabular}


DHPLC analysis, aliquots of $10 \mu \mathrm{l}$ of PCR products were injected for $0.1 \mathrm{~min}$ on a semiautomated Wave- 3500 system (Transgenomic, Omaha, NE, USA).

Analysis took in general approximately 7-8 min including column regeneration and re-equilibration to starting conditions. The column mobile phase consisted of gradient mixture of $0.1 \mathrm{M}$ triethylamine acetate (TEAA) ( $\mathrm{pH} 7.0$ ) with buffer B (0.1 M TEAA and 25\% acetonitrile). Temperature for successful resolution of heteroduplex molecules was determined by running fragment-specific melting curves and by using the DHPLC melting algorithm WAVE Maker of the WAVE instrument (Table 2). Data were analyzed using Navigator 1.5.3 software (Transgenomic). Samples with a variation in peak shape when compared to the control samples (DNA from people without PD symptoms) were sequenced with both forward and reverse primers.

Purified amplicons were sequenced in both directions using BigDye Terminator v1.1 Cycle Sequencing Kit (Applied Biosystems, UK) in the forward and reverse directions and resolved on an ABI 3130xl automated sequencer (Applied Biosystems, UK), analysed with DNA Sequencing Analysis v5.2 (Applied Biosystems, UK) and ChromasPro v1.5 software (Technelyisium Pty Ltd., Australia).

\section{Results}

In our cohort of 216 early and late onset PD cases we detected one heterozygous missense mutation p.Arg275Trp (R275W,
c.823C $>\mathrm{T}, \mathrm{rs} 34424986$ ) in exon 7 of the parkin (PARK2) gene in one patient. In addition, we identified one polymorphism in intron 2 of this gene and seven intronic and one exonic polymorphisms within LRRK2 gene (Table 3 ). The polymorphisms identified in LRRK2 intron 47: IVS47-91insGCCAT, IVS47-91insGCAT and IVS47-20C>T are novel. In order to predict a possible effect of these variants on exon splicing we used the online Human Splicing Finder (version 2.4.1, link: http://www.umd.be/HSF/) software. HSF predicted the IVS47-20C > T variant to create a new potential silencer motif within intron. The IVS47-91insGCCAT and IVS4791insGCAT create new potential acceptor splice sites.

The DNA analysis of the parents and other family members of the patients carrying the polymorphisms or R275W mutation was not possible, thus no segregation of variants with the disease could be followed.

In the exons 31 and 41 of gene the LRKK2, and in exon 6 of the gene parkin we did not observe any variant chromatographic profile after DHPLC analyses.

\section{Discussion}

In our variable cohort of $216 \mathrm{PD}$ cases we identified in one female patient the presence of a single exon 7 parkin (PARK2) gene mutation $\mathrm{R} 275 \mathrm{~W}$ in heterozygous state. This patient had the age at onset 61 years and her first symptom was a tremor on their right hand. Hoehn-Yahr stage was 3. She was administered dopamine agonist MPX 1.2,

Table 3. Polymorphisms found in Slovak population

\begin{tabular}{|c|c|c|c|c|}
\hline Allele & Accession $\mathrm{N}^{\circ}$ & Frequency of allele $\mathrm{p}(\mathrm{A})$ & Genotypes & $n$ \\
\hline \multirow{2}{*}{$L R R K 2$ in $35:$ IVS35+23T $>A$} & \multirow{2}{*}{ rs7307276 } & \multirow{2}{*}{0.3773} & IVS35+23T>A(hetero) & 39 \\
\hline & & & IVS35+23T $>\mathrm{A}($ homo $)$ & 62 \\
\hline \multirow{2}{*}{ LRRK2 in 47: IVS47-91insGCCAT } & \multirow{2}{*}{ novel } & \multirow{2}{*}{0.0278} & IVS47-91insGCCAT(hetero) & 12 \\
\hline & & & IVS47-91insGCCAT(homo) & 0 \\
\hline \multirow{2}{*}{ LRRK2 in47: IVS47-91insGCAT } & \multirow{2}{*}{ novel } & \multirow{2}{*}{0.7315} & IVS47-91insGCAT(hetero) & 42 \\
\hline & & & IVS47-91insGCAT(homo) & 137 \\
\hline \multirow{2}{*}{$L R R K 2$ in 47: IVS47-90A $>\mathrm{G}$} & \multirow{2}{*}{ rs56026228 } & \multirow{2}{*}{0.0116} & IVS47-90A>G(hetero) & 5 \\
\hline & & & IVS47-90A>G(homo) & 0 \\
\hline \multirow{2}{*}{$L R R K 2$ in 47: IVS47-41A $>\mathrm{G}$} & \multirow{2}{*}{ rs 184962630} & \multirow{2}{*}{0.0023} & IVS47-41A>G(hetero) & 1 \\
\hline & & & IVS47-41A>G(homo) & 0 \\
\hline \multirow{2}{*}{$L R R K 2$ in 47: IVS47-20C $>\mathrm{T}$} & \multirow{2}{*}{ novel } & \multirow{2}{*}{0.0046} & IVS47-20C > T(hetero) & 2 \\
\hline & & & IVS47-20C>T(homo) & 0 \\
\hline \multirow{2}{*}{ LRRK2 in47: IVS47-9delT } & \multirow{2}{*}{ rs11317573 } & \multirow{2}{*}{0.5138} & IVS47-9delT(hetero) & 84 \\
\hline & & & IVS47-9delT(homo) & 69 \\
\hline \multirow{2}{*}{ LRRK2 ex48: 7155A>G } & \multirow{2}{*}{ rs33962975 } & \multirow{2}{*}{0.0926} & 7155A>G(hetero) & 38 \\
\hline & & & $7155 \mathrm{~A}>\mathrm{G}$ (homo) & 1 \\
\hline \multirow{2}{*}{ parkin ex2: IVS2+25T>C } & \multirow{2}{*}{ rs111356273 } & \multirow{2}{*}{0.1829} & IVS2+25T>C(hetero) & 75 \\
\hline & & & IVS2+25T>C(homo) & 2 \\
\hline
\end{tabular}

$n$, the number of subjects carrying this genotype (among 216 pacients). 
monoamine oxidase inhibitor (MAO-B) Azilect, and she showes no fluctuations. In intron 2 of the parking gene also the presence of known polymorphism was identified.

No mutations of the $L R R K 2$ gene were found in tested group. However, the presence of seven intronic and one exonic $L R R K 2$ variant was observed, all within intron 47.

The only mutation identified in our cohort, R275W, affects the RING1 domain of parkin and it is one of the most frequent amino acid change within this gene, confirming previous reports from other European studies (Abbas et al. 1999; Hedrich et al. 2004; von Coelln et al. 2004; Sironi et al. 2008).

Sriram and co-workers suggested that the R275W mutation could impair the ubiquitin-proteasome system through sequestration into aggresome-like structures in the cell and away from their site of normal function (West et al. 2002; Sriram et al. 2005).

Drosophila model overexpressing R275W mutation was found to exhibit dopaminergic degeneration and mitochondrial abnormalities similar to parkin knockout flies, including mitochondria with large vacuoles, concentric membranous structures, disorganized cristae, or degenerated membranes. These studies suggest that parkin plays a key role in maintaining mitochondrial stability in certain cell types (Wang et al. 2007).

Two mutant isoforms, R256C and R275W, within RING finger 1 of the Parkin protein (238-293 amino acids), produced an unusual distribution of the protein, with large cytoplasmic and nuclear inclusions. Cookson et al. (2003) replicated this observation in primary cultured neurons and demonstrate, by the accumulation/co-localization of cytoskeletal protein vimentin, that the inclusion bodies are aggresomes, a cellular response to misfolded protein.

The range of the so far reported parkin mutations varies from point mutations to complex rearrangements including deletions and/or multiplications of complete exons. Oliveira et al. found the RING1 mutations primarly in heterozygous PD patients with a much later age at onset (mean AAO: 49.2 years) but were not found in controls in their study or several previous reports. These findings suggest that mutations in parkin contribute to the common form of PD and that heterozygous mutations, especially those lying in exon 7 , act as susceptibility alleles for late-onset form of Parkinson disease (Oliveira et al. 2003). Also our patient, carrier of R275W, has the age at onset rather high - 61 years.

In the study of Sironi et al. (2008), the father of two affected siblings developed a classical late onset PD. He was a carrier of R275W.

Several other studies suggest that a single parkin mutation may cause EOPD or represent a risk factor for lateonset PD (Foroud et al 2003; Bertoli-Avella et al. 2005; Sun et al. 2006; Deng et al. 2008). The association of parkin haploinsufficiency in sporadic Parkinson's disease further implicates the role of parkin in the more common form of the disease.

However, pathogenicities of parkin mutations, especially those in heterozygotes, remain controversial, possibly due to confusions caused by the "mixed" effects of all types of mutations (Wang et al. 2010).

The single heterozygous state might exert haploinsufficiency effects rather than dominant negative effects. By contrast, some missense mutations might have a dominant negative effect as missense mutations in functional domains (Ubl or RINGS), resulting in an earlier onset than with mutations in other regions (Lohmann et al. 2003; Hattori and Mizuno 2004).

In order to evaluate the role of heterozygous mutations in $\mathrm{PD}$, as observed in our patient, it is necessary to compare their frequencies in patients and controls. Brüggemann and co-workers demonstrated that a clinical follow-up investigation of mutation carriers is important to assess the mutation frequency in truly unaffected individuals. While the implications of heterozygous mutations in PD cannot be conclusively determined, previous data point to a role as a susceptibility factor that is able to cause at least subtle signs of PD later in life. Therefore, they suggested to perform further prospective studies in older controls, in conjunction with a careful neurological examination, in order to elucidate the clinical relevant question of how many of them will eventually develop PD (Brüggemann et al. 2009). Thus, the control study requires large control group and long follow up of potentially identified mutation carriers, which was not possible in our pilotal study.

In the few patients in whom only a single heterozygous parkin mutation was detected, it is possible that a second mutation escaped identification by the methods employed, or that some mutations in heterozygous forms are sufficient to cause disease (Klein et al. 2000).

Interestingly, heterozygous mutations in other autosomal recessive $\mathrm{PD}$ genes have also been associated with the development of $\mathrm{PD}$, most clearly for carriers of a heterozygous PINK1 mutation (Abou-Sleiman et al. 2006; Hedrich et al. 2006). Such heterozygous mutations in recessive PD genes may modify the phenotype in patients with mutations in other PD genes (Klein et al. 2007; Funayama et al. 2008).

Several mutations rather frequent in different populations were not present in our cohort. One example is R1441G associated with PD in the Basque region (Gorostidi et al. 2009, Mata et al. 2009a). Similarly, no carriers of R1441G, R1441C, or R1441H mutations were found among our cases.

The LRRK2 G2019S mutation is the most frequent known cause of familial and sporadic PD. A heterogeneous distribution was observed with high frequencies in North African Arab countries, the Middle East, southern Europe, North American Ashkenazi Jewish populations and in South American countries with known European ethnic influence. 
Frequencies ranged from the no cases to $35.7 \%$ in sporadic and $42 \%$ in familial North-African Arab patients (Brás et al. 2005; Lesage et al. 2005, 2006, 2008; Clark et al. 2006; Deng et al. 2006; Gaig et al. 2006; Goldwurm et al. 2006; Infante et al. 2006; Ozelius et al. 2006; Marongiu et al. 2006; Mata et al. 2006, 2009b; Civitelli et al. 2007; Cossu et al. 2007; Ferreira et al. 2007; González-Fernández et al. 2007; Ishihara et al. 2007; Orr-Urtreger et al. 2007; Perez-Pastene et al. 2007; Squillaro et al. 2007; Hulihan et al. 2008; Munhoz et al. 2008; Pimentel et al. 2008; Correia Guedes et al. 2009; De Rosa et al. 2009; Floris et al. 2009; Gorostidi et al. 2009).

There were not found any known pathogenic mutations (G2019S or I2020T) within exon 41 of LRRK2 gene in the studied patients. This result of the case doesn't differ from the studies which were made with other European populations: Austria, Poland, Holland, Belgium, or from Africa: Niger, or from Asia: Taiwan, Singapore, South Korea (Calne et al. 1992; Bialecka et al. 2005; Lu et al. 2005; Mata et al. 2005; Tan et al. 2005; Fung et al. 2006; Farrer et al. 2007; Cho et al. 2007; Haubenberger et al. 2007; Choi et al. 2008; Lin et al. 2008; Nuytemans et al. 2008; Okubadejo et al. 2008; Macedo et al. 2009).

First of the polymorphisms identified in our cohort, IVS35+23T $>\mathrm{A}$ in LRRK2, was described first time by Schlitter et al. 2006 in a German cohort of 120 patients (Schlitter et al. 2006). The pathogenic role is unknown. Frequency in our group of patients was $38 \%$.

LRRK2 variant IVS47-41G>A was found in $0.8 \%$ frequency in a $60 \mathrm{PD}$ families and wasn't present in the control sample (Di Fonzo et al. 2006a). However, the authors descibed that the IVS47-41G $>$ A doesn't cosegregate with the disease (Di Fonzo et al. 2006b). In our group this polymorphism was present only in $0.2 \%$. The patient carrying this variant had rigidity of muscles, age at onset was 63 . He takes levodopa (Stalevo 600) and amantidin without fluctuations. The Hoehn-Yahr score was 3.

Two groups desribed the intronic variant IVS47-9delT of LRRK2 as non pathogenic (Di Fonzo et al. 2006b, Shojaee et al. 2009). In our cohort it was present at frequency of 51\%.

This silent point mutation (c.7155A $>$ G, p.Gly2385Gly) in exon 48 of the LRRK2 gene is located in the WD40 domain and change the codon from GGA to GGG. Mata et al. and Di Fonzo et al. found this variant with similar frequency in cases and controls, therefore this change was considered as neutral (Mata et al. 2005; Di Fonzo et al. 2006a). The frequency was $9 \%$ of this allele in our group of patients.

The parkin intron 2 variant IVS $2+25 \mathrm{~T}>\mathrm{C}$ was identified by Abbas et al. (1999). They found this change also in control subjects and have concluded that this change is not sufficient to cause PD by themselves in European population. In our group of patients was the frequency of this allele $19 \%$.

We identified also novel polymorphisms with possible role in the pathogenesis of PD. Two patients carried the
IVS47-20C $>\mathrm{T}$ polymorphism within intron 47 of $L R R K 2$. The first patient had age at onset 56 years. Her first symptom was tremor on their right hand, she had Hoehn-Yahr score 3. She takes MAO B inhibitor (Azilect) and dopamine agonist (MPX 1.2) without fluctuations. The second patient with this variant was 71 years old when the first symptoms (tremor on their right hand) appeared. The Hoehn-Yahr score was 2.5. He use levodopa (Stalevo 600) without fluctuation, but he had mild dementia (treated with Exelon). As the Human splicing finder indicates (http://www.umd.be/HSF/), this variation may create new potential silencer regulatory element that might negatively affect correct exon splicing.

$L R R K 2$ variants IVS47-91 insGCCAT and LRRK2 IVS4791insGCAT were present in cca. $88 \%$ of patients in our group. The in silico HSF analysis showed that these intronic variants appear to significantly modify the recognition of natural splice site. They can create a potential new acceptor splice sites. However, further studies employing patients and controls' splice product are required in order to test for the effect on splicing of these 3 novel variants.

It can be concluded that the point mutations in exons 31, 35, 41, 48 of LRRK2 gene and in exons 2, 6, 7 of parkin causes rarely Parkinson disease in Slovak republic, which corroborates data from other studies from countries of Central/Eastern Europe.

However, we could not completely exclude the possibility that the patients carry other mutations or rearrangements within tested genes, because no molecular analysis was performed of all exons of the LRRK2 and PARK2 genes. In the follow up of this study also a gene dosage studies, especially of PARK2 gene have to be considered, in order to uncover possible larger genomic deletions. We also plan to perform the genetic screening of other genes (e.g. SNCA, PINK1, DJ-1) possibly involed in the pathogenesis of PD in Slovak patients.

Acknowledgement. We are grateful to the patients and their families. This project was supported by the VEGA 2/055/09 grant.

Conflict of interest statement: We declare that we have no conflict of interest.

\section{References}

Abbas N., Lücking C. B., Ricard S., Dürr A., Bonifati V., De Michele G., Bouley S., Vaughan J. R., Gasser T., Marconi R., Broussolle E., Brefel-Courbon C., Harhangi B. S., Oostra B. A., Fabrizio E., Böhme G. A., Pradier L., Wood N. W., Filla A., Meco G., Denefle P., Agid Y., Brice A. (1999): A wide variety of mutations in the parkin gene are responsible for autosomal recessive parkinsonism in Europe. French Parkinson's Disease Genetics Study Group and the European Consortium on Genetic Susceptibility in Parkinson's Disease. Hum. Mol. Genet. 8, 567-574 
http://dx.doi.org/10.1093/hmg/8.4.567

Abou-Sleiman P. M., Muqit M. M., McDonald N. Q., Yang Y. X., Gandhi S., Healy D. G., Harvey K., Harvey R J., Deas E., Bhatia K., Quinn N., Lees A., Latchman D. S., Wood N. W. (2006): A heterozygous effect for PINK1 mutations in Parkinson's disease? Ann. Neurol. 60, 414-419 http://dx.doi.org/10.1002/ana.20960

Bertoli-Avella A. M., Giroud-Benitez J. L., Akyol A., Barbosa E., Schaap O., van der Linde H. C., Martignoni E., Lopiano L., Lamberti P., Fincati E., Antonini A., Stocchi F., Montagna P., Squitieri F., Marini P., Abbruzzese G., Fabbrini G., Marconi R., Dalla Libera A., Trianni G., Guidi M., De Gaetano A., Boff Maegawa G., De Leo A., Gallai V., de Rosa G., Vanacore N., Meco G., van Duijn C. M., Oostra B. A., Heutink P. (2005): Novel parkin mutations detected in patients with early-onset Parkinson's disease. Mov. Disord. 20, 424-431 http://dx.doi.org/10.1002/mds.20343

Bialecka M., Hui S., Klodowska-Duda G., Opala G., Tan E. K., Drozdzik M. (2005): Analysis of LRRK 2 G 2019 S and I 2020 T mutations in Parkinson's disease. Neurosci. Lett. 390, 1-3 http://dx.doi.org/10.1016/j.neulet.2005.07.045

Biswas A., Gupta A., Naiya T., Das G., Neogi R., Datta S., Mukherjee S., Das S. K., Ray K., Ray J. (2006): Molecular pathogenesis of Parkinson's disease: indentification of mutations in the Parkin gene in Indian patients. Parkinsonism Relat. Disord. $7,420-426$ http://dx.doi.org/10.1016/j.parkreldis.2006.04.005

Bonifati V., Rizzu P., van Baren M. J., Schaap O., Breedveld G.J., Krieger E., Dekker M. C. J., Squitieri F., Ibanez P., Joosse M., van Dongen J. W., Vanacore N., van Swieten J. C., Brice A., Meco G., van Duijn C. M., Oostra B. A., Heutink P. (2003): Mutations in the DJ-1 gene associated with autosomal recessive early-onset parkinsonism. Science 299, 256-258

http://dx.doi.org/10.1126/science.1077209

Brás J. M., Guerreiro R. J., Ribeiro M. H., Januário C., Morgadinho A., Oliveira C. R., Cunha L., Hardy J., Singleton A. (2005): G2019S dardarin substitution is a common cause of Parkinson's disease in a Portuguese cohort. Mov. Disord. 20, 1653-1655 http://dx.doi.org/10.1002/mds.20682

Brüggemann N., Mitterer M., Lanthaler A. J., Djarmati A., Hagenah J., Wiegers K., Winkler S., Pawlack H., Lohnau T., Pramstaller P. P., Klein C., Lohmann K. (2009): Frequency of heterozygous Parkin mutations in healthy subjects: need for careful prospective follow-up examination of mutation carriers. Parkinsonism. Relat. Disord. 15, 425-429 http://dx.doi.org/10.1016/j.parkreldis.2008.11.014

Calne S., Schoenberg B., Martin W., Uitti R. J., Spencer P., Calne D. B. (1987): Familial Parkinson's disease: possible role of environmental factors. Canad. J. Neurol. Sci. 14, 303-305

Calne D. B., Snow B. J., Lee C. (1992): Criteria for diagnosing Parkinson's disease. Ann. Neurol. 32, 125-127 http://dx.doi.org/10.1002/ana.410320721 Cho J. W., Kim S. Y., Park S. S., Kim H. J., Ahn T. B., Kim J. M., Jeon B. S. (2007): The G2019S LRRK2 mutation is rare in Korean patients with Parkinson's disease. Can. J. Neurol. Sci. 34, 53-55

Choi J. M., Woo M. S., Ma H. I., Kang S. Y., Sung, Y. H., Yong S. W., Chung S. J., Kim J. S., Shin H., Lyoo C. H., Lee P. H., Baik J. S., Kim S. J., Park M. Y., Sohn Y. H., Kim J. H., Kim J. W., Lee M.
S., Lee M. C., Kim D. H., Kim Y.J. (2008): Analysis of PARK genes in a Korean cohort of early-onset Parkinson disease. Neurogenetics 9, 263-269

http://dx.doi.org/10.1007/s10048-008-0138-0

Civitelli D., Tarantino P., Nicoletti G., Candiano I. C. C., Annesi F., Marco E. V., Carrideo S., Rocca F. E., Condino F., Spadafora P., Pugliese P., D‘Asero S., Morelli M., Paglionico S, Annesi G., Quattrone A. (2007): LRRK2 G6055A mutation in Italian patients with familial or sporadic Parkinson's disease. Clin. Genet. 71, 367-370 http://dx.doi.org/10.1111/j.1399-0004.2007.00771.x

Clark L. N., Wang Y., Karlins E., Saito L., Mejia-Santana H., Harris J., Louis E. D., Cote L. J., Andrews H., Fahn S., Waters C., Ford B., Frucht S., Ottman R., Marder K. (2006): Frequency of LRRK2 mutations in early- and late-onset Parkinson disease. Neurology 67, 1786-1791 http://dx.doi.org/10.1212/01.wnl.0000244345.49809.36

Cookson M. R., Lockhart P. J., McLendon C., O'Farrell C., Schlossmacher M., Farrer M. J. (2003): RING finger 1 mutations in Parkin produce altered localization of the protein. Hum. Mol. Genet. 12, 2957-2965 http://dx.doi.org/10.1093/hmg/ddg328

Correia Guedes L., Ferreira J. J., Rosa M. M., Coelho M., Bonifati V., Sampaio C. (2009): Worldwide frequency of G2019S LRRK2 mutation in Parkinson's disease: a systematic review. Parkinsonism Relat. Disord. 16, 237-242 http://dx.doi.org/10.1016/j.parkreldis.2009.11.004

Cossu G., van Doeselaar M., Deriu M., Melis M., Molari A., Di Fonzo A., Oostra B. A., Bonifati V. (2007): LRRK2 mutations and Parkinson's disease in Sardinia e a Mediterranean genetic isolate. Parkinsonism Relat. Disord. 13, 17-21 http://dx.doi.org/10.1016/j.parkreldis.2006.06.010

De Rosa A., Criscuolo C., Mancini P., De Martino M., Giordano I. A., Pappata S., Filla A., De Michele G. (2009): Genetic screening for LRRK2 gene G2019S mutation in Parkinson's disease patients from Southern Italy. Parkinsonism Relat. Disord. 15, $242-244$ http://dx.doi.org/10.1016/j.parkreldis.2008.05.011

Deng H., Le W., Guo Y., Hunter C. B., Xie W., Huang M., Jankovic J. (2006): Genetic analysis of LRRK2 mutations in patients with Parkinson disease. J. Neurol. Sci. 251, 102-106 http://dx.doi.org/10.1016/j.jns.2006.09.017

Deng H., Le W., Shahed J., Xie W., Jankovic J. (2008): Mutation analysis of the parkin and PINK1 genes in American Caucasian early-onset Parkinson disease families. Neurosci. Lett. 430, $18-22$ http://dx.doi.org/10.1016/j.neulet.2007.10.018

Di Fonzo A., Rohe Ch. F., Ferreira J., Chien H. F., Vacca L., Stocchi F., Guedes L., Fabrizio E., Manfredi M., Vanacore N., Goldwurm S., Breedweld G., Sampaio C., Meco G. G., Barbosa E., Di Fonzo A., Wu-Chou Y. H., Lu C. S., van Doeselaar M., Simons E.J., Rohe C.F., Chang H. C., Chen R. S., Weng Y. H., Vanacore N., Breedveld G. J., Oostra B. A., Bonifati V. (2006a): A common missense variant in the LRRK2 gene, Gly2385Arg, associated with Parkinson's disease risk in Taiwan. Neurogenetics 7, 133-138 http://dx.doi.org/10.1007/s10048-006-0041-5

Di Fonzo A., Tassorelli C., De Mari M., Chien H. F., Ferreira J., Rohé C.F., Riboldazzi G., Antonini A., Albani G., Mauro A., 
Marconi R., Abbruzzese G., Lopiano L., Fincati E., Guidi M., Marini P., Stocchi F., Onofrj M., Toni V., Tinazzi M., Fabbrini G., Lamberti P., Vanacore N., Meco G., Leitner P., Uitti R. J., Wszolek Z. K., Gasser T., Simons E J., Breedveld G. J., Goldwurm S., Pezzoli G., Sampaio C., Barbosa E., Martignoni E., Oostra B. A., Bonifati V. (2006b): Italian Parkinson's Genetics Network. Comprehensive analysis of the LRRK2 gene in sixty families with Parkinson's disease. Eur. J. Hum. Genet. 14, 322-331 http://dx.doi.org/10.1038/sj.ejhg.5201539

Dudek H., Datta S. R., Franke T. F., Birnbaum M. J., Yao R., Cooper G. M., Segal R. A., Kaplan D. R., Greenberg M. E. (1997): Regulation of neuronal survival by the serine-threonine protein kinase Akt. Science. 275, 661-665 http://dx.doi.org/10.1126/science.275.5300.661

PMid:9005851 Eriksen J. L., Wszolek Z., Petrucelli L. (2005): Molecular pathogenesis of Parkinson disease. Arch. Neurol. 62, 353-357 http://dx.doi.org/10.1001/archneur.62.3.353

Farrer M. J., Stone J. T., Lin C. H., Dächsel J. C., Hulihan M. M., Haugarvoll K., Ross O. A., Wu R. M. (2007): Lrrk2 G2385R is an ancestral risk factor for Parkinson's disease in Asia. Parkinsonism Relat. Disord. 13, 89-92 http://dx.doi.org/10.1016/j.parkreldis.2006.12.001

Ferreira J. J., Correia Guedes L., Rosa M. M., Coelho M., van Doeselaar M., Di Fonzo A., Oostra B. A., Sampaio C., Bonifati V. (2007): High prevalence of LRRK2 mutations in familial and sporadic Parkinson's disease in Portugal. Mov. Disord. 22, 1194-1201 http://dx.doi.org/10.1002/mds.21525

Floris G., Cannas A., Solla P., Murru M. R., Tranquilli S., Corongiu D., Rolesu M., Cuccu S., Sardu C., Marrosu F., Marrosu M G. (2009): Genetic analysis for five LRRK2 mutations in a Sardinian parkinsonian population. Importance of G2019S and R1441C mutations in sporadic Parkinson's disease patients. Parkinsonism Relat. Disord. 15, 277-280 http://dx.doi.org/10.1016/j.parkreldis.2008.06.009

Foroud T., Uniacke S. K., Liu L., Pankratz N., Rudolph A., Halter C., Shults C., Marder K., Conneally P. M., Nichols W. C. (2003): Parkinson Study Group. Heterozygosity for a mutation in the parkin gene leads to later onset Parkinson's disease. Neurology 60, 796-801 http://dx.doi.org/10.1212/01.WNL.0000049470.00180.07

Funayama M., Hasegawa K., Kowa H., Saito M., Tsuji S., Obata F. (2002): A new locus for Parkinson's disease (PARK8) maps to chromosome 12p11.2-q13.1. Ann. Neurol. 51, 296-301 http://dx.doi.org/10.1002/ana.10113

Funayama M., Li Y., Tsoi T. H., Lam C. W., Ohi T., Yazawa S., Uyama E., Djaldetti R., Melamed E., Yoshino H., Imamichi Y., Takashima H., Nishioka K., Sato K., Tomiyama H., Kubo S., Mizuno Y., Hattori N. (2008): Familial Parkinsonism with digenic parkin and PINK1 mutations. Mov. Disord. 23, 1461-1465 http://dx.doi.org/10.1002/mds.22143

Fung H. C., Chen C. M., Hardy J., Hernandez D., Singleton A., Wu Y. R. (2006): Lack of G2019S LRRK2 mutation in a cohort of Taiwanese with sporadic Parkinson's disease. Mov. Disord. 21, 880-881 http://dx.doi.org/10.1002/mds.20814
Gaig C., Ezquerra M., Marti M. J., Muñoz E., Vallderiola F., Tolosa E. (2006): LRRK2 mutations in Spanish patients with Parkinson's disease. Arch. Neurol. 63, 377-382 http://dx.doi.org/10.1001/archneur.63.3.377

Goldwurm S., Zini M., Di Fonzo A., De Gaspari D., Siri C., Simons E. J., van Doeselaar M., Tesei S., Antonini A., Canesi M., Zecchinelli A., Mariani C., Meucci N., Sacilotto G., Cilia R., Isaias I. U., Bonetti A., Sironi F., Ricca S., Oostra B. A., Bonifati V., Pezzoli G. (2006): LRRK2 mutations and Parkinson's disease: a clinical, neuropsychological and neuropsychiatric study in a large Italian sample. Parkinsonism Relat. Disord. 12, 410-419 http://dx.doi.org/10.1016/j.parkreldis.2006.04.001

González-Fernández M. C., Lezcano E., Ross A. O., Gómez-Esteban J. C., Gómez-Busto F., Velasco F., Alvarez-Alvarez M., Rodríguez-Martínez M. B., Ciordia R., Zarranz J. J., Farrer M. J., Mata I. F., de Pancorbo M. M. (2007): Lrrk2-associated parkinsonism is a major cause of disease in Northern Spain. Parkinsonism Relat, Disord. 13, 509-515 http://dx.doi.org/10.1016/j.parkreldis.2007.04.003

Gorostidi A., Ruiz-Martinez J., Lopez de Munain A., Alzualde A., Marti Masso J. F. (2009): LRRK2 G2019S and R1441G mutations associated with Parkinson's disease are common in the Basque country, but relative prevalence is determined by ethnicity. Neurogenetics 10, 157-159 http://dx.doi.org/10.1007/s10048-008-0162-0

Hattori N., Mizuno Y.(2004): Pathogenetic mechanisms of parkin in Parkinson's disease. Lancet 364, 722-724 http://dx.doi.org/10.1016/S0140-6736(04)16901-8

Haubenberger D., Bonelli S., Hotzy C., Leitner P., Lichtner P., Samal D., Katzenschlager R., Djamshidian A., Brücke T., Steffelbauer M., Bancher C., Grossmann J., Ransmayr G., Strom T. M., Meitinger T., Gasser T., Auff E., Zimprich A. (2007): A novel LRRK2 mutation in an Austrian cohort of patients with Parkinsons disease. Mov. Disord. 22, 1640-1643 http://dx.doi.org/10.1002/mds.21568

Haylett W. L., Keyser R. J., du Plessis M. C., van der Merwe C., Blanckenberg J., Lombard D., Carr J., Bardien S. (2011): Mutations in the parkin gene are a minor cause of Parkinson's disease in the South African population. Parkinsonism Relat. Disord. 18, 89-92 http://dx.doi.org/10.1016/j.parkreldis.2011.09.022

Hedrich K., Eskelson C., Wilmot B., Marder K., Harris J., Garrels J., Meija-Santana H., Vieregge P., Jacobs H., Bressman S. B., Lang A. E., Kann M., Abbruzzese G., Martine- lli P., Schwinger E., Ozelius L. J., Pramstaller P. P., Klein C., Kramer P. (2004): Distribution, type, and origin of parkin mutations: review and case studies. Mov. Disord. 19, 1146-1157 http://dx.doi.org/10.1002/mds.20234

Hedrich K., Hagenah J., Djarmati A., Hiller A., Lohnau T., Lasek K., Grünewald A., Hilker R., Steinlechner S., Boston H., Kock N., Schneider-Gold C., Kress W., Siebner H., Binkofski F., Lencer R., Münchau A., Klein C. (2006): Clinical spectrum of homozygous and heterozygous PINK1 mutations in a large German family with Parkinson disease: role of a single hit? Arch. Neurol. 63, 833-838 http://dx.doi.org/10.1001/archneur.63.6.833

Healy D. G., Falchi M., O‘Sullivan S. S., Bonifati V., Durr A., Bressman S., Brice A., Aasly J., Zabetian C. P., Goldwurm S., Ferreira 
J. J., Tolosa E., Kay D. M., Klein C., Williams D. R., Marras C., Lang A. E., Wszolek Z. K., Berciano J., Schapira A. H., Lynch T., Bhatia K. P., Gasser T., Lees A. J., Wood N.W. (2008): International LRRK2 Consortium. Phenotype, genotype, and worldwide genetic penetrance of LRRK2-associated Parkinson's disease: a case-control study. Lancet Neurol. 7, 583-590 http://dx.doi.org/10.1016/S1474-4422(08)70117-0

Hulihan M. M., Ishihara-Paul L., Kachergus J., Warren L., Amouri R., Elango R., Prinjha R. K., Upmanyu R., Kefi M., Zouari M., Sassi S. B., Yahmed S. B., El Euch-Fayeche G., Matthews P. M., Middleton L. T., Gibson R. A., Hentati F., Farrer M. J. (2008): LRRK2 Gly2019Ser penetrance in ArabeBerber patients from Tunisia: a case-control genetic study. Lancet Neurol. 7, 591-594 http://dx.doi.org/10.1016/S1474-4422(08)70116-9

Infante J., Rodriguez E., Combarros O., Mateo I., Fontalba A., Pascual J., Oterino A., Polo J. M., Leno C., Berciano J. (2006): LRRK2 G2019S is a common mutation in Spanish patients with late-onset Parkinson's disease. Neurosci. Lett. 395, 224-226 http://dx.doi.org/10.1016/j.neulet.2005.10.083

Ishihara L., Gibson R. A., Warren L., Amouri R., Lyons K., Wielinski C., Hunter C., Swartz J. E., Elango R., Akkari P. A., Leppert D., Surh L., Reeves K. H., Thomas S., Ragone L., Hattori N., Pahwa R., Jankovic J., Nance M., Freeman A., Gouider-Khouja N., Kefi M., Zouari M., Ben Sassi S., Ben Yahmed S., El EuchFayeche G., Middleton L., Burn D. J., Watts R. L., Hentati F. (2007): Screening for LRRK2 G2019S and clinical comparison of Tunisian and North American Caucasian Parkinson's disease families. Mov. Disord. 22, 55-61 http://dx.doi.org/10.1002/mds.21180

Kachergus J., Mata I. F., Hulihan M., Taylor J.P., Lincoln S., Aasly J., Gibson J.M., Ross O. A., Lynch T., Wiley J., Payami H., Nutt J., Maraganore D. M., Czyzewski K., Styczynska M., Wszolek Z. K., Farrer M. J., Toft M. (2005): Identification of a novel LRRK2 mutation linked to autosomal dominant parkinsonism: evidence of a common founder across European populations. Am. J. Hum. Genet. 76, 672-680 http://dx.doi.org/10.1086/429256

Kitada T., Asakawa S., Hattori N., Matsumine H., Yamamura Y., Minoshima S., Yokochi M., Mizuno Y., Shimizu N. (1998): Mutations in the parkin gene cause autosomal recessive juvenile parkinsonism. Nature 392, 605-608 http://dx.doi.org/10.1038/33416

Klein C., Pramstaller P. P., Kis B., Page C. C., Kann M., Leung J., Woodward H., Castellan C. C., Scherer M., Vieregge P., Breakefield X. O., Kramer P. L., Ozelius L. J. (2000): Parkin deletions in a family with adult-onset, tremor-dominant Parkinsonism: expanding the phenotype. Ann. Neurol. 48, 65-71 http://dx.doi.org/10.1002/1531-8249(200007)48:1<65::AID-ANA10>3.0.CO;2-L

Klein C., Lohmann-Hedrich K., Rogaeva E., Schlossmacher M. G., Lang A. E. (2007): Deciphering the role of heterozygous mutations in genes associated with parkinsonism. Lancet Neurol. 6, 652-662 http://dx.doi.org/10.1016/S1474-4422(07)70174-6

Lesage S., Ibanez P., Lohmann E., Pollak P., Tison F., Tazir M., Leutenegger A. L., Guimaraes J., Bonnet A. M., Agid Y., Dürr A., Brice A. (2005): French Parkinson's Disease Genetics Study Group. G2019S LRRK2 mutation in French and North African families with Parkinson's disease. Ann. Neurol. 58, 784-787

http://dx.doi.org/10.1002/ana.20636

Lesage S., Durr A., Tazir M., Lohmann E., Leutenegger A. L., Janin S., Pollak P., Brice A. (2006): French Parkinson's Disease Genetics Study Group. LRRK2 G2019S as a cause of Parkinson's disease in North African Arabs. N. Engl. J. Med. 354, 422-423 http://dx.doi.org/10.1056/NEJMc055540

Lesage S., Belarbi S., Troiano A., Condroyer C., Hecham N., Pollak P., Lohman E., Benhassine T., Ysmail-Dahlouk F., Dürr A., Tazir M., Brice A. (2008); French Parkinson's Disease Genetics Study Group. Is the common LRRK2 G2019S mutation related to dyskinesias in North African Parkinson disease? Neurology 71, 1550-1552

Lin C. H., Tzen K. Y., Yu C. Y., Tai C. H., Farrer M. J., Wu R. M. (2008): LRRK2 mutation in familial Parkinson's disease in a Taiwanese population: clinical, PET, and functional studies. J. Biomed. Sci. 15, 661-667 http://dx.doi.org/10.1007/s11373-008-9260-0

Lohmann E., Periquet M., Bonifati V., Wood N. W., De Michele G., Bonnet A. M., Fraix V., Broussolle E., Horstink M. W., Vidailhet M., Verpillat P., Gasser T., Nicholl D., Teive H., Raskin S., Rascol O., Destée A., Ruberg M., Gasparini F., Meco G., Agid Y., Durr A., Brice A. (2003): French Parkinson's Disease Genetics Study Group; European Consortium on Genetic Susceptibility in Parkinson's Disease. How much phenotypic variation can be attributed to parkin genotype? Ann. Neurol. 54, 176-185

http://dx.doi.org/10.1002/ana.10613

Lu C. S., Simons E. J., Wu-Chou Y. H., Di Fonzo A., Chang H. C., Chen R. S., Weng Y. H., Rohé C. F., Breedveld G. J., Hattori N., Gasser T., Oostra B. A., Bonifati V. (2005): The LRRK2 I2012T, G2019S and I2020T mutations are rare in Taiwanese patients with sporadic Parkinson's disease. Parkinsonism Relat. Disord. 11, 521-522 http://dx.doi.org/10.1016/j.parkreldis.2005.09.003

Lücking C. B., Dürr A., Bonifati V., Vaughan J., De Michele G., Gasser T., Harhangi B. S., Meco G., Denèfle P., Wood N. W., Agid Y., Brice A. (2000): French Parkinson's Disease Genetics Study Group, European Consortium on Genetic Susceptibility in Parkinson's Disease, Association between early-onset Parkinson's disease and mutations in the parkin gene. N. Eng. J. Med. 342, 1560-1567 http://dx.doi.org/10.1056/NEJM200005253422103

Macedo M. G., Verbaan D., Fang Y., van Rooden S. M., Visser M., Anar B., Uras A, Groen J. L., Rizzu P., van Hilten J. J., Heutink P. (2009): Genotypic and phenotypic characteristics of Dutch patients with early onset Parkinson's disease. Mov. Disord. 24, 196-203 http://dx.doi.org/10.1002/mds.22287

Manning B. D., Cantley L. C. (2007): AKT/PKB signaling: navigating downstream. Cell. 129, 1261-1274 http://dx.doi.org/10.1016/j.cell.2007.06.009

Marongiu R., Guezzi D., Lalongo T., Soleti F., Elia A., Cavone S., Albanese A., Altavista M. C., Barone P., Brusa L., Cortelli P., Petrozzi L., Scaglione C., Stanzione P., Tinazzi M., Zeviani M., Dallapiccola B., Bentivoglio A. R., Valente E. M., Garavaglia B. (2006): Italian. Frequency and phenotypes of LRRK2 G2019S 
mutation in Italian patients with Parkinson's disease. Mov. Disord. 21, 1232-1235

http://dx.doi.org/10.1002/mds.20890

Mata I. F., Kachergus J. M., Taylor J. P., Lincoln S., Aasly J., Lynch T., Hulihan M. M., Cob S. A., Wu R. M., Lu C. S., Lahoz C., Wszolek Z. K., Farrer M. J. (2005): Lrrk2 pathogenic substitutions in Parkinson's disease. Neurogenetics 6, 171-177 http://dx.doi.org/10.1007/s10048-005-0005-1

Mata I. F., Ross O. .A, Kachergus J., Huerta C., Ribacoba R., Moris G., Blazquez M., Guisasola L. M., Salvador C., Martinez C., Farrer M., Alvarez V. (2006): LRRK2 mutations are a common cause of Parkinson's disease in Spain. Eur. J. Neurol. 13, 391-394 http://dx.doi.org/10.1111/j.1468-1331.2006.01256.x

Mata I. F., Hutter C. M., Gonzalez-Fernandez M. C., de Pancorbo M. M., Lezcano E., Huerta C., Blazquez M., Ribacoba R., Guisasola L. M., Salvador C., Gomez-Esteban J. C., Zarranz J. J., Infante J., Jankovic J., Deng H., Edwards K. L., Alvarez V., Zabetian C. P. (2009a): Lrrk2 R1441G-related Parkinson's disease: evidence of a common founding event in the seventh century in Northern Spain. Neurogenetics 10, 347-353 http://dx.doi.org/10.1007/s10048-009-0187-z

Mata I. F., Cosentino C., Marca V., Torres L., Mazzetti P., Ortega O., Raggio V, Aljanati R, Buzó R., Yearout D., Dieguez E., Zabetian C. P. (2009b): LRRK2 mutations in patients with Parkinson's disease from Peru and Uruguay. Parkinsonism Relat. Disord. 15, 370-373 http://dx.doi.org/10.1016/j.parkreldis.2008.09.002

Matsumine H., Yamamura Y., Kobayashi T., Nakamura S., Kuzuhara S., Mizuno Y. (1998): Early onset parkinsonism with diurnal fluctuation maps to a locus for juvenile parkinsonism. Neurology 50, 1340-1345 http://dx.doi.org/10.1212/WNL.50.5.1340

Moore D. J., West A. B., Dawson V. L., Dawson T. M. (2005): Molecular pathophysiology of Parkinson's disease. Annu. Rev. Neurosci. 28, 57-87 http://dx.doi.org/10.1146/annurev.neuro.28.061604.135718

Munhoz R. P., Wakutani Y., Marras C., Teive H. A., Raskin S., Werneck L. C., Moreno D., Sato C., Lang A. E., Rogaeva E. (2008): The G2019S LRRK2 mutation in Brazilian patients with Parkinson's disease: phenotype in monozygotic twins. Mov. Disord. 23, 290-294 http://dx.doi.org/10.1002/mds.21832

Nussbaum R. L., Polymeropoulos M. H. (1997): Genetics of Parkinson's disease. Hum. Molec. Genet. 6, 1687-1691 http://dx.doi.org/10.1093/hmg/6.10.1687

Nuytemans K., Rademakers R., Theuns J., Pals P., Engelborghs S., Pickut B., de Pooter T., Peeters K., Mattheijssens M., Van den Broeck M., Cras P., De Deyn P. P., van Broeckhoven C. (2008): Founder mutation p.R1441C in the Leucine-rich repeat kinase 2 gene in Belgian Parkinson's disease patients. Eur. J. Hum. Genet. 16, 471-479 http://dx.doi.org/10.1038/sj.ejhg.5201986

Ohta E, Kawakami F, Kubo M, Obata F. (2011): LRRK2 directly phosphorylates Akt1 as a possible physiological substrate: impairment of the kinase activity by Parkinson's disease-associated mutations. FEBS Lett. 585, 2165-2170 http://dx.doi.org/10.1016/j.febslet.2011.05.044
Okubadejo N., Britton A., Crews C., Akinyemi R., Hardy J., Singleton A., Bras J. (2008): Analysis of Nigerians with apparently sporadic Parkinson disease for mutations in LRRK2, PRKN and ATXN3. PloS ONE. 3, 3421

http://dx.doi.org/10.1371/journal.pone.0003421

Oliveira S. A., Scott W. K., Martin E. R., Nance M. A., Watts R. L., Hubble J. P., Koller W. C., Pahwa R., Stern M. B., Hiner B. C., Ondo W. G., Allen F. H., Scott B. L., Goetz C. G., Small G. W., Mastaglia F., Stajich J. M., Zhang F., Booze M. W., Winn M. P., Middleton L. T., Haines J. L., Pericak-Vance M. A., Vance J. M. (2003): Parkin mutations and susceptibility alleles in late-onset Parkinson's disease. Ann. Neurol. 53, 624-629

http://dx.doi.org/10.1002/ana.10524

Orr-Urtreger A., Shifrin C., Rozovski U., Rosner S., Bercovich D., Gurevich T., Yagev-More H., Bar-Shira A., Giladi N. (2007): The LRRK2 G2019S mutation in Ashkenazi Jews with Parkinson disease: isthere a gender effect? Neurology 69, 1595-1602 http://dx.doi.org/10.1212/01.wnl.0000277637.33328.d8

Ozelius L. J, Senthil G., Saunders-Pullman R., Ohmann E., Deligtisch A., Tagliati M., Hunt A. L., Klein C., Henick B., Hailpern S. M., Lipton R. B., Soto-Valencia J., Risch N., Bressman S. B. (2006): LRRK2 G2019S as a cause of Parkinson's disease in Ashkenazi Jews. N. Engl. J. Med. 354, 424-425 http://dx.doi.org/10.1056/NEJMc055509

Paisan-Ruiz C., Jain S., Evans E. W., Gilks W. P., Simon J., van der Brug M., Lopez de Munain A., Aparicio S., Gil A. M., Khan N., Johnson J., Martinez J. R., Nicholl D., Carrera I. M., Pena A. S., de Silva R., Lees A., Marti-Masso J. F., Perez-Tur J., Wood N. W., Singleton A. B. (2004): Cloning of the gene containing mutations that cause PARK8-linked Parkinson's disease. Neuron 44, 595-600 http://dx.doi.org/10.1016/j.neuron.2004.10.023

Perez-Pastene C., Cobb S. A., Díaz-Grez F., Hulihan M. M., Miranda M., Venegas P., Venegas P, Godoy O. T., Kachergus J. M., Ross O. A., Layson L., Farrer M. J., Segura-Aguilar J. (2007): Lrrk2 mutations in South America: a study of Chilean Parkinsons disease. Neurosci. Lett. 422, 193-197 http://dx.doi.org/10.1016/j.neulet.2007.06.021

Periquet M., Latouche M., Lohmann E., Rawal N., De Michele G., Ricard S., Teive H., Fraix V., Vidailhet M., Nicholl D., Barone P., Wood N. W., Raskin S., Deleuze J. F., Agid Y., Dürr A., Brice A. (2003): French Parkinson's Disease Genetics Study Group; European Consortium on Genetic Susceptibility in Parkinson's Disease. Parkin mutations are frequent in patients with isolated early-onset parkinsonism. Brain. 126, $1271-1278$ http://dx.doi.org/10.1093/brain/awg136

Pimentel M. M., Moura K. C., Abdalla C. B., Pereira J. S., de Rosso A. L., Nicaretta D. H., Campos M. Jr., de Almeida R. M., dos Santos J. M., Bastos I. C., Mendes M. F., Maultasch H., Costa F. H., Werneck A. L., Santos-Rebouças C. B. (2008): A study of LRRK2 mutations and Parkinson's disease in Brazil. Neurosci. Lett. 433, 17-21 http://dx.doi.org/10.1016/j.neulet.2007.12.033

Polymeropoulos M. H., Higgins J. J., Golbe L. I., Johnson,W. G., Ide S. E., Di Iorio G., Sanges G., Stenroos E. S., Pho L. T., Schaffer A. A., Lazzarini A. M., Nussbaum R. L., Duvoisin R. C. (1996): 
Mapping of a gene for Parkinson's disease to chromosome 4q21-q23. Science 274, 1197-1198

http://dx.doi.org/10.1126/science.274.5290.1197

Polymeropoulos M. H., Lavedan C., Leroy E., Ide S. E., Dehejia A. Dutra A., Pike B., Root H., Rubenstein J., Boyer R., Stenroos E. S., Chandrasekharappa S., Athanassiadou A., Papapetropoulos T., Johnson W. G., Lazzarini A. M., Duvoisin R. C., Di Iorio G., Golbe L. I., Nussbaum R. L. (1997): Mutation in the alphasynuclein gene identified in families with Parkinson's disease. Science 276, 2045-2047 http://dx.doi.org/10.1126/science.276.5321.2045

Punia S., Behari M., Govindappa S. T., Swaminath P. V., Jayaram S., Goyal V., Muthane U. B., Juyal R. C., Thelma B. K. (2006): Absence/rarity of commonly reported LRRK2 mutations in Indian Parkinson's disease patients. Neurosci. Lett. 409, 83-88 http://dx.doi.org/10.1016/j.neulet.2006.04.052

Ross O. A., Wu Y. R., Lee M. C., Funayama M., Chen M. L., Soto A. I., Mata I. F., Lee-Chen G. J., Chen C. M., Tang M., Zhao Y., Hattori N., Farrer M. J., Tan E. K., Wu R.M. (2008): Analysis of Lrrk2 R1628P as a risk factor for Parkinson's disease. Ann. Neurol. 64, 88-92 http://dx.doi.org/10.1002/ana.21405

Sasaki S., Shirata A., Yamane K., Iwata M. (2004): Parkin-positive autosomal recessive juvenile Parkinsonism with alpha-synuclein-positive inclusions. Neurology. 63, 678-682 http://dx.doi.org/10.1212/01.WNL.0000134657.25904.0B

Schlitter A. M., Woitalla D., Mueller T., Epplen J. T., Dekomien G. (2006): The LRRK2 gene in Parkinson's disease: mutation screening in patients from Germany. J. Neurol. Neurosurg. Psychiatry 77, 891-892 http://dx.doi.org/10.1136/jnnp.2005.083022

Shimura H., Hattori N., Kubo S., Mizuno Y., Asakawa S., Minoshima S., Shimizu N., Iwai K., Chiba T., Tanaka K., Suzuki T. (2000): Familial Parkinson disease gene product, Parkin, is a ubiquitin-protein ligase. Nat. Genet. 25, 302-305 http://dx.doi.org/10.1038/77060

Shojaee S., Sina F., Farboodi N., Fazlali Z., Ghazavi F., Ghorashi S.A., Parsa K., Sadeghi H., Shahidi G. A., Ronaghi M., Elahi E. (2009): A clinic-based screening of mutations in exons 31, 34, 35,41 , and 48 of LRRK2 in Iranian Parkinson's disease patients. Mov. Disord. 24, 1023-1027 http://dx.doi.org/10.1002/mds.22503

Simón-Sánchez J., Martí-Massó J. F, Sánchez-Mut J. V, Paisán-Ruiz C., Martínez-Gil A., Ruiz-Martínez J., Sáenz A., Singleton A. B., López de Munain A., Pérez-Tur J. (2006): Parkinson's disease due to the R1441G mutation in Dardarin: a founder effect in the Basques. Mov. Disord. 11, 1954-1959 http://dx.doi.org/10.1002/mds.21114

Sironi F., Primignani P., Zini M., Tunesi S., Ruffmann C., Ricca S., Brambilla T., Antonini A., Tesei S., Canesi M., Zecchinelli A., Mariani C., Meucci N., Sacilotto G., Cilia R., Isaias I. U., Garavaglia B., Ghezzi D., Travi M., Decarli A., Coviello D. A., Pezzoli G., Goldwurm S.(2008): Parkin analysis in early onset Parkinson's disease. Parkinsonism Relat. Disord. 14, 326-333 http://dx.doi.org/10.1016/j.parkreldis.2007.10.003

Squillaro T., Cambi F., Ciacci G., Rossi S., Ulivelli M., Malandrini A., Mencarelli M. A., Mari F., Renieri A., Ariani F.
(2007): Frequency of the LRRK2 G2019S mutation in Italian patients affected by Parkinson's disease. J. Hum. Genet. 52, 201-204

http://dx.doi.org/10.1007/s10038-006-0105-2

Sriram S. R., Li X., Ko H. S., Chung K. K. K., Wong E., Lim K. L., Dawson V. L., Dawson T. M. (2005): Familial-associated mutations differentially disrupt the solubility, localization, binding and ubiquitination properties of parkin. Hum. Molec. Genet. 14, 2571-2586 http://dx.doi.org/10.1093/hmg/ddi292

Sun M., Latourelle J. C., Wooten G. F., Lew M. F., Klein C., Shill H. A., Golbe L. I., Mark M. H., Racette B. A., Perlmutter J. S., Parsian A., Guttman M., Nicholson G., Xu G., Wilk J. B., Saint-Hilaire M. H., DeStefano A. L., Prakash R., Williamson S., Suchowersky O., Labelle N., Growdon J. H., Singer C., Watts R. L., Goldwurm S., Pezzoli G., Baker K. B., Pramstaller P. P., Burn D. J., Chinnery P. F., Sherman S., Vieregge P., Litvan I., Gillis T., MacDonald M. E., Myers R. H., Gusella J. F. (2006): Influence of heterozygosity for parkin mutation on onset age in familial Parkinson disease: the GenePD study. Arch. Neurol. 63, 826-832 http://dx.doi.org/10.1001/archneur.63.6.826

Takahashi H., Ohama E., Suzuki S., Horikawa Y., Ishikawa A., Morita T., Tsuji S., Ikuta F. (1994): Familial juvenile parkinsonism: clinical and pathologic study in a family. Neurology 44, 437-441 http://dx.doi.org/10.1212/WNL.44.3_Part_1.437

Tan E. K., Shen H., Tan L. C., Farrer M., Yew K., Chua E., Jamora R. D., Puvan K., Puong K. Y., Zhao Y., Pavanni R., Wong M. C., Yih Y., Skipper L., Liu J. J. (2005): The G2019S LRRK2 mutation is uncommon in an Asian cohort of Parkinson's disease patients. Neurosci. Lett. 384, 327-329 http://dx.doi.org/10.1016/j.neulet.2005.04.103

Tan E. K., Zhao Y., Skipper L., Tan M. G., Di Fonzo A., Sun L., Fook-Chong S., Tang S., Chua E., Yuen Y., Tan L., Pavanni R., Wong M. C., Kolatkar P., Lu C. S., Bonifati V., Liu J. J. (2007): The LRRK2 gly2385-to-arg variant is associated with Parkinson's disease: genetic and functional evidence. Hum. Genet. 120, 857-863 http://dx.doi.org/10.1007/s00439-006-0268-0

Valente E. M., Abou-Sleiman P.M., Caputo V., Muqit M. M., Harvey K., Gispert S., Ali Z., Del Turco D., Bentivoglio A. R., Healy D.G., Albanese A., Nussbaum R., Gonzalez-Maldonado R., Deller T., Salvi S., Cortelli P., Gilks W. P., Latchman D. S., Harvey R. J., Dallapiccola B., Auburger G., Wood N. W. (2004): Hereditary early-onset Parkinson's disease caused by mutations in PINK1. Science 304, 1158-1160 http://dx.doi.org/10.1126/science.1096284

von Coelln R., Dawson V. L., Dawson T. M. (2004): Parkin-associated Parkinsons disease. Cell Tissue. Res. 318, 175-184 http://dx.doi.org/10.1007/s00441-004-0924-4

Wang C., Lu R., Quyang X., Ho M. W., Chia W., Yu F., Lim K. L. (2007): Drosophila overexpressing parkin R275W mutant exhibits dopaminergic neuron degeneration and mitochondrial abnormailities. J. Neurosci. 27, 8563-8570 http://dx.doi.org/10.1523/JNEUROSCI.0218-07.2007

Wang C., Ma H., Feng X., Xie S., Chan P. (2010): Parkin dosage mutations in patients with early/onset sporadic and familiar 
Parkinson's disease in Chinese: an independent pathogenic role. Brain. Res. 1358, 30-38 http://dx.doi.org/10.1016/j.brainres.2010.08.060

West A., Periquet M., Lincoln S., Lücking C. B., Nicholl D., Bonifati V., Rawal N., Gasser T., Lohmann E., Deleuze J. F., Maraganore D., Levey A., Wood N., Dürr A., Hardy J., Brice A., Farrer M. (2002): French Parkinson's Disease Genetics Study Group and the Complex relationship between parkin mutations and Parkinson disease. Am. J. Med. Genet. 114, 584-591

http://dx.doi.org/10.1002/ajmg.10525

Zimprich A., Biskup S., Leitner P., Lichtner P., Farrer M., Lincoln S., Kachergus J., Kulihan M., Uitti R. J., Calne D. B., Stoessl A. J., Pfeiffer R. F., Patenge N., Carbajal I. C., Vieregge P., Asmus F., Muller-Myhsok B., Dickson D. W., Meitinger T., Strom T.
M., Wszolek Z. K., Gasser T. (2004a): Mutations in LRRK2 cause autosomal-dominant parkinsonism with pleomorphic pathology. Neuron 44, 601-607

http://dx.doi.org/10.1016/j.neuron.2004.11.005

Zimprich A., Muller-Myhsok B., Farrer M., Leitner P., Sharma M., Huilhan M., Lockhart P., Calne D. B., Stoessl J., Uitti R. J., Pfeiffer R. F., Trenkwalder C., Homann N., Ott E., Wenzel K., Asmus F., Hardy J., Wszolek Z., Gasser T. (2004b): The PARK8 locus for autosomal dominant parkinsonism: confirmation of linkage and further delineation of the disease-containing interval. Am. J. Hum. Genet. 74, 11-19 http://dx.doi.org/10.1086/380647

Received: January 11, 2012

Final version accepted: November 7, 2012 